\title{
Studies on the Gametophyte of Selaginella.
}

\author{
BY \\ D. H. CAMPBELL, \\ Professor of Botany in the Stanford University, California, U.S.A. \\ With Plate XIX.
}

\begin{abstract}
SEVERAL years ago the writer undertook the study of $S$ the development of the female gametophyte in Selaginella Kraussiana, and the results were published in brief form ${ }^{1}$. Before their publication a paper by Heinsen ${ }^{2}$ appeared, and since then four other contributions have been made, by Arnoldi ${ }^{3}$, Bruchmann ${ }^{4}$, Fitting ${ }^{5}$, and Lyon ${ }^{6}$. Of these, the most important was the paper by Fitting, who corrected an error into which all previous investigators had fallen, the mistaking of the very much contracted protoplast of the young spore for the nucleus. Fitting also made a most satisfactory study of the development of the spore membranes. The most recent paper on the subject is by Miss Lyon. This is a somewhat extended study of the development of two native species, S. apus and S.rupestris. The most interesting point recorded by Miss Lyon is the retention of the macro-

${ }^{1}$ Structure and Development of the Mosses and Ferns, pp. 485-504, 1895.

${ }^{2}$ Die Macrosporen und das weibliche Prothallium von Selaginella, Flora, 78 , 1894 .

${ }^{3}$ Die Entwickelung des weiblichen Vorkeims bei den heterosporen Lycopodiaceen. Bot. Zeit. 54 , 1896 .

${ }^{4}$ Untersuchungen über Selaginella spinulosa. Gotha, I897.

5 Flora, I900.

6 A Study of the Sporangia and Gametophytes of Selaginella apus and Selaginella rupestris. Bot. Gazette, xxxii, August-September, IgoI.
\end{abstract}

[Annals of Botany, Vol. XVI. No. LXIII. September, I902.]

G $\mathrm{g}$ 
spore within the sporangium until after the fertilization of the archegonia. Miss Lyon also confirms Fitting's account of the real nature of the protoplasmic vesicle of the young macrospore.

Miss Lyon, in her paper, criticizes the work of the writer on $S$. Kraussiana, and this led to a re-examination of the preparations upon which the account was based as well as the making of a number of new preparations of the same species. The result was to confirm in every detail the statements previously made, with the single exception of the point which had been corrected in Fitting's paper. Being at a loss to see how Miss Lyon could have reached such very different results, she was written to on the subject, and it turned out that she had misunderstood the writer's use of the term 'spore-cavity,' which was interpreted as synonymous with 'vacuole.' In reality her results agreed closely with those of the writer. It seemed well, however, to make a definite statement as to the real facts in the case, especially as the new preparations filled several gaps which had been left in the older series of preparations.

\section{METHODS.}

The earlier preparations were made from material fixed with I $\%$ chromic acid, double-stained with alum-cochineal and Bismarck-brown. In making the new preparations Flemming's weak solution was used for fixing, and the triple safranin-gentian-violet-orange stain was employed. In this way, especially in the younger stages, very beautiful differentiation of the nuclei was obtained. In the later stages, especially after the spore-cavity became completely filled up, the strongly staining coarse albuminous granules often made it difficult to clearly recognize the nuclei.

In fixing the spores and embedding them for sectioning the individual spores were removed from the sporangia and sectioned separately. Owing to the brittle exospore, some trouble was experienced in sectioning, but by using hard paraffine this was to some extent corrected. 


\section{THE SPORE-MEMBRANES.}

During its earlier stages, the growth of the massive and complex membrane is almost entirely due to the activity of the tapetal cells of the sporangium. As was pointed out by the writer ${ }^{1}$, the extremely small amount of protoplasm in the young spore could not account for the massive wall developed at a very early period. Fitting's demonstration that the small and delicate protoplasmic vesicle of the young spore is almost free from the wall emphasized this, and the writer has been able to verify his results for S. Kraussiana, and Miss Lyon has done the same for $S$. apus and S. rupestris. It is highly probable that all species agree essentially in this respect.

The process is, in brief, as follows. The young spore shows a small globular vesicle near the apex, which is very evident in the fresh spore, and has the appearance of a large nucleus, for which it was taken until Fitting pointed out its true nature. This vesicle is the protoplast of the spore, and grows much more slowly than the membrane, between which and the protoplast a large cavity is developed (Pl. XIX, Fig. I). At an early stage, the thick membrane separates into two layers, the 'exospore' and 'mesospore' (Fitting). These are in contact at the apex of the spore, but the former enlarges more rapidly than the latter, and thus a second space is formed (Figs. I, 2). The single small nucleus of the young spore divides at an early stage, and this division is repeated, the protoplasmic vesicle enlarging as the nuclear divisions proceed.

At this stage (Fig. I) the exospore in section appears as a thick, strongly staining layer, with marked sharp perinium or ridges upon its outer surface. These in S. Kraussiana form a reticulate pattern upon the outside of the spore. The mesospore $(m)$ presents much the same appearance as the exospore, but is of nearly uniform thickness. It looks as if it were formed by the splitting off of an inner layer from the exospore. Miss Lyon, in her description of the spore-coats,

\section{1. c. p. 504 .}

G g 2 
calls this the endospore, apparently overlooking the development of the true cellulose endospore which arises later in contact with the protoplast. She also mentions a layer (mesospore) between the two thick layers (exospore and mesospore of Fitting), but no evidence of such a membrane was found in S. Kraussiana which agrees essentially with $S$. Helvetica as described and figured by Fitting. The principal difference lay in the mesospore being thinner than in that species, and remaining more nearly of the same thickness in the earlier and later stages; thus indicating that its increase in size in the late stages was due to actual growth, and not to mere stretching.

Between the protoplast and the mesospore and between the latter and the exospore the space is filled with what appears to be a fluid, doubtless containing plastic material derived from the tapetum. In all the preparations examined, this substance appeared perfectly homogeneous, staining pale purple or blue with gentian-violet (Fig. 2). No trace of the peculiar fibrillae figured by Miss Lyon ${ }^{1}$ in the species studied by her, could be seen, and it would be well if a further examination could be made in these species to determine whether or not this fibrillar appearance is due to the action of reagents.

As to the nomenclature of the various spore-membranes, it might be better to use the term 'epispore' or 'perinium' for the outer, sculptured membrane, considering the 'mesospore' as the equivalent of the exospore of the lower archegoniates.

\section{The Female Gametophyte.}

The very peculiar behaviour of the early stages in the development of the gametophyte was first made clear by Fitting. He showed that the vesicle supposed to be the nucleus by all previous observers was in reality the whole protoplast, which forms a very small, extremely delicate membrane containing the single small nucleus. Heinsen gave 
an accurate figure of this stage, but interpreted the nucleus as a nucleolus. Miss Lyon, in her work on S. apus and $S$. mpestris, fully confirmed Fitting's statement, and the writer has found the same condition to obtain in S. Kraussiana.

Fig. I shows a transverse section of a young spore of this species, made a short distance back of the apex. The primary nucleus was divided into four, these being much flattened. The very thin protoplasmic vesicle is still free from the mesospore. The nuclei continue to divide, but this takes place slowly, and does not keep pace with the rapid expansion of the protoplasmic vesicle, which soon becomes closely applied to the inner surface of the mesospore. The vesicle is so thin as to be scarcely discernible, except where it has become detached from the mesospore. The latter increases rapidly in size, the protoplasmic vesicle keeping pace with it, and finally the mesospore again comes into close contact with the exospore. The protoplasm is still reduced to an exceedingly thin film which may be very easily overlooked, and the nuclei are small and widely scattered. Neither at this stage, nor in any subsequent ones, are the nuclei in S. Kraussiana confined to the apical region of the spore, as Miss Lyon states is the case in the species examined by her.

The protoplasmic layer now begins to thicken rapidly, and the nuclei increase in number, and also become larger and lose their flattened form (Fig. 4). For some reason, possibly because the fixing process was slow, no karyokinetic figures were encountered in the earlier stages, but there is no reason for supposing that the division is amitotic, as Heinsen ${ }^{1}$ suggests.

The structure of the nucleus is somewhat peculiar. Its contour is clearly marked and there is present a central nucleolus-like body which stains very strongly, but the rest of the nuclear cavity appears quite destitute of anything which could be interpreted as a nuclear filament or chromatin. In later stages (Fig. I4), the central mass sometimes appears

$$
1 \text { 1. c. p. } 478 \text {. }
$$


to be composed of crowded granules, and it seems probable that the apparent nucleolus is really composed of chromatin; the structure being, perhaps, comparable to that of the nucleus of Spirogyra and some other Algae.

The protoplasmic layer thickens more rapidly at the apical region, where the nuclei are also more numerous (Figs. 6, 8). Instead of the nuclei at the apex being in six or seven layers as described by Miss Lyon for the species examined by her ${ }^{1}$, in $S$. Kraussiana they are mainly restricted to a single layer, although there may be an occasional nucleus below this (Fig. 8). In regard to the first cell-formation, S. Kraussiana seems to differ widely from either $S$. apus or $S$. rupestris. There is no trace of the preliminary blocking out of protoplasmic areas by protoplasmic fibrillae, but the first divisions are effected at once by cell-walls (Figs. 8, 9). These form simultaneously between the nuclei in the central part of the apical region, precisely as in ordinary endosperm-formation. The central cells (areoles) thus formed are regularly hexagonal in form, and usually contain but a single nucleus. Toward the margin of the prothallial disc they are larger and more irregular, and may contain two or more nuclei. Whether the formation of these walls is immediately preceded by nuclear division could not be determined. Faint indications of connecting fibres between the nuclei could be seen in some cases, but these were not very evident, and in the few cases where the young walls were found all of the nuclei were in the resting stage.

The areoles thus formed are open below (Fig. 8), but between this stage and that where the prothallial disc was complete no stages could be found, and the exact method by which the subsequent cell-formation takes place must be left for future investigation. Presumably the next nuclear divisions are in a radial direction, and are accompanied by the formation of cells-walls which result in the development of the definite cellular disc, or primary prothallium which is found at the apex of the ripe spore (Fig. IO). This disc consists of 
a single superficial layer of small cells, beneath which, in the central portion, may usually be found two others. At the margins the disc is reduced to a single layer. As the spore ripens, the walls of the lower cells become much thickened and form the diaphragm $(d)$, separating the prothallia disc from the thick layer of protoplasm which lines the spore cavity (Fig. II).

The protoplasmic layer thickens until the vacuole, which at first occupies very much the larger part of the spore cavity, becomes very much reduced in size (Fig. 10), but at the time that the spore is ripe it is still evident. Neither at this time nor at an earlier stage was there found in the microtome sections any trace of oil or any solid matter. If oil is present in the living spore, it was entirely dissolved out in the process of embedding. Some time after germination begins the vacuole closes completely, and in a few preparations, before this was completed, the vacuole showed a spongy-looking mass filling it.

In the later stages the nuclei lying in the cytoplasm immediately below the diaphragm (Fig. I2) are much smaller than those in the basal part of the spore (Fig. I3), and much more numerous. The cytoplasm below the diaphragm is more finely granular than at the base of the spore ; and everything indicates that it is more active, which is what might be expected, as it is here that the secondary cell-formation begins after the fertilization of the archegonium.

In the later stages of germination the development of coarse masses of proteid materials which stain deeply makes the study of the nuclei difficult, and they are by no means easy to demonstrate at this time.

Comparing Miss Lyon's account of the gametophyte of $S$. apus with that of S. Kraussiana, the first difference is the much greater development of the primary prothallium of the former, which consists of six to seven layers of cells instead of the three usually occurring in S. Kraussiana. To judge from the figures, there are two types of prothallium in $S$. apus, one in which there is a sharp demarcation of the base of the 
primary prothallium, and one where apparently there is no interruption in its development. It is not quite clear from Miss Lyon's account what is the history of the part of the spore-cavity below the prothallium. She states that the vacuole becomes filled with an emulsion and later with a semi-solid mass of granular matter, and that neither in the central nor basal part of the spore-cavity are nuclei present at any period of its development. It is impossible to determine from her figures whether any protoplasm is present in the lower part of the spore, as everything below the apical mass of cells is represented as absolutely similar; it being impossible to say where the protoplasm (if any) ends, and the vacuole begins. Fig. 57 of her paper shows the whole spore-cavity to be ultimately filled with cellular tissue, which implies the presence of nuclei, thus contradicting the assertion that at no period are nuclei found in the central or basal part of the gametophyte. This raises the question, whether proper standing will not reveal the presence of nuclei in the basal part of the spore-cavity before the cell-formation begins.

\section{The Male Gametophyte.}

Miss Lyon's account of the development of the male gametophyte and antheridium differs widely from that of previous investigators, especially Belajeff ${ }^{1}$. It cannot be said, however, that either her account or figures are quite convincing. From an examination of sections of the earlier stages in S. Kraussiana there seemed little reason to doubt that the masses surrounding the groups of sperm-cells are, as they have every appearance of being and were interpreted by Belajeff, cells, and not mere structureless masses of foodstuff developed in vacuoles. Owing to the dense granules, which stain strongly and resemble nuclei, the presence of the latter, as in the later stages of the female gametophyte, is difficult to demonstrate, but in several instances what seemed to be undoubted nuclei were seen. The formation of the

1 Antheridien und Spermatozoiden der heterosporen Lycopodiaceen. Bot. Zeit. 43,1885 . 
groups of sperm-cells by a process of free cell-formation, like that of ascospores, is, to say the least, improbable, and must be positively demonstrated before it can be accepted.

\section{The Older Gametophyte.}

The later stages of the gametophyte, the structure, and development of the archegonium were not further investigated, as these have been sufficiently described and figured by the writer before.

\section{SUMMARY.}

I. Fitting's account of the development of the sporemembranes and the character of the protoplast in the young spore was confirmed.

2. Except for the mistake of interpreting the young protoplast as the nucleus of the young spore, the account previously published by the writer was found correct in every particular.

3. The nuclei in Selaginella Kraussiana are uniformly distributed through the cytoplasm of the young spore; later they are more numerous in the apical region, where the cytoplasmic layer is also thicker.

4. No preliminary blocking out of nucleated areas takes place, but cell-walls are formed at once. The primary cells ('areoles') are at first open below.

5. A definite cellular body (primary prothallium) is formed at the apex of the spore. This is a disc, usually composed of three layers of cells in its central part. The inner walls of the lower layer of cells become thickened, and form a diaphragm separating the primary prothallium from the undivided sporecavity below.

6. The cytoplasm of the spore-cavity increases rapidly in amount, so that the central vacuole becomes much reduced in size, but it is still evident when the spores are shed. Ultimately it becomes completely obliterated. Except in the very latest stages it is quite free from granular contents, appearing entirely empty in microtome sections. 


\section{Campbell. - Studies on Gametophyte of Selaginella.}

7. The nuclei in the cytoplasm just below the diaphragm are smaller and more numerous than those in the basal part of the spore. The central body is probably not a nucleolus, but a mass of chromatin.

8. The masses surrounding the complex of sperm-cells in the germinated microspores are probably true cells.

\section{EXPLANATION OF FIGURES IN PLATE XIX.}

Illustrating Professor Campbell's paper on the Gametophyte of Selaginella.

All figures refer to Selaginella Kraussiana, A. Br. All camera drawings from microtome sections. Figs. I, 2, Leitz, oc. I, ob. 7 ; Fig. Io, Leitz, oc. 3, ob. 3 ; the others Leitz oil im. $\frac{1}{16}$ oc. I. $E x$. exospore; $m$. mesospore ; pr. protoplast; $n$. nuclei ; $v$. vacuole; $d$. diaphragm.

Fig. I. Transverse section of young macrospore; the protoplasmic vesicle, $p r$, still free from the mesospore, $m$. Two of the four nuclei of the spore are shown in the section.

Fig. 2. Nearly median longitudinal section of an older spore, the protoplasmic vesicle in close contact with the mesospore.

Fig. 3. $a$, part of a similar section more highly magnified. $b$, a single nucleus seen from above.

Fig. 4. An older stage; the cytoplasmic layer has thickened and the nuclei are no longer flattened.

Fig. 5. Surface view of a portion of the cytoplasmic layer with the nuclei.

Fig. 6. Nearly median section through the apex of the spore shortly before the first cell-formation, showing the thickened cytoplasmic layer and nuclei.

Fig. 7. Section of the cytoplasmic layer of the same spore, near the base.

Fig. 8. Beginning of cell-formation at the apex of the spore. The areoles are still open below.

Fig. 9. Transverse section through the young prothallium, showing the regular form of the central cells.

Fig. Io. Nearly median longitudinal section of a ripe spore; the primary gametophyte, $g$, separated from the cytoplasm of the spore-cavity by a diaphragm; many nuclei are scattered through the cytoplasm and the vacuole is still present. The outer spore membranes are not shown.

Fig. II. Median section of the central part of the prothallium, showing the diaphragm separating it from the spore-cavity.

Fig. I2. Cytoplasm and nuclei from the upper part of the spore-cavity.

Fig. I3. Part of the basal cytoplasm and nuclei from the same spore.

Fig. I4. A single nucleus showing the nucleolus-like central chromatin mass, composed, apparently, of several crowded granules. 

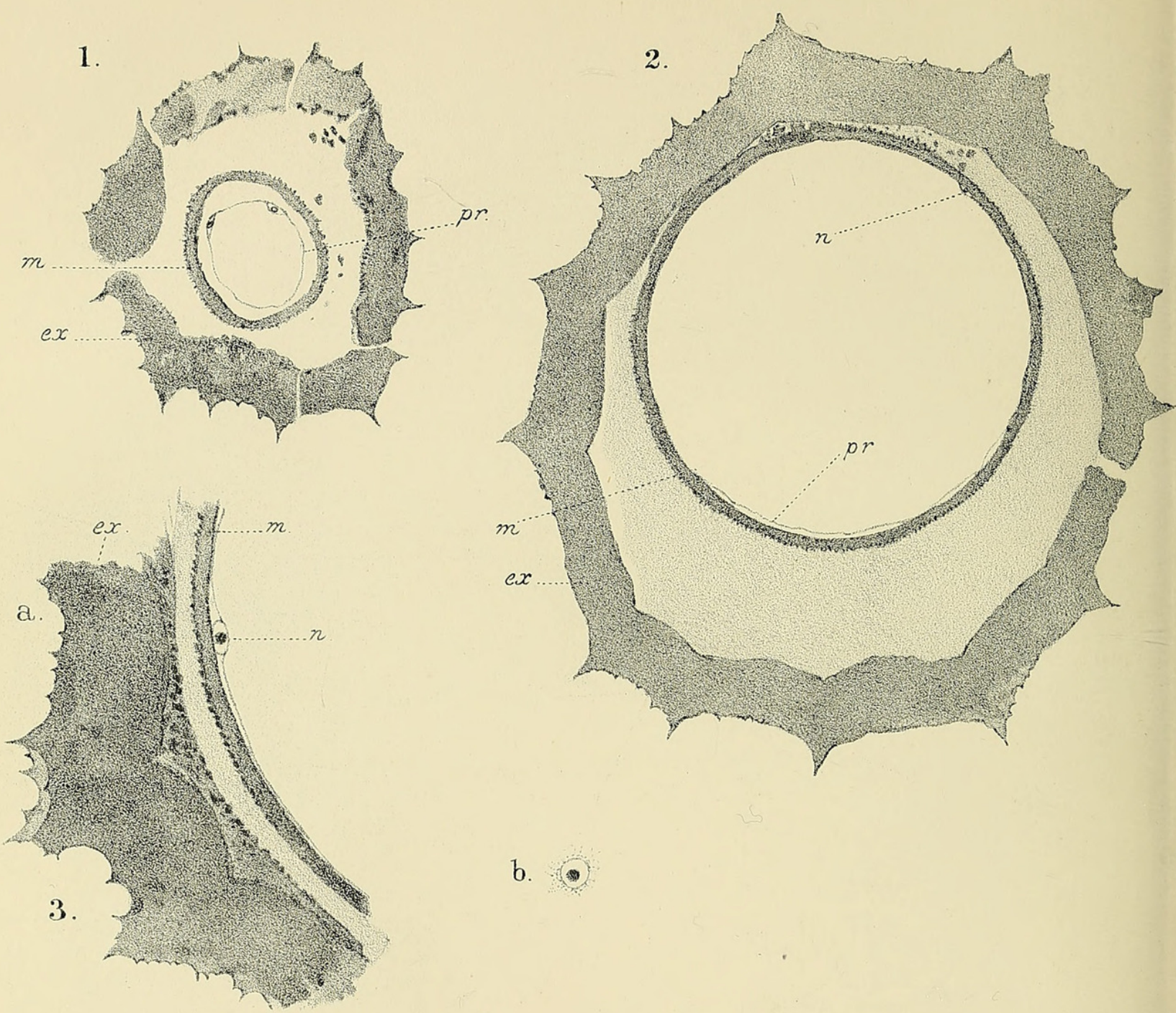

b.

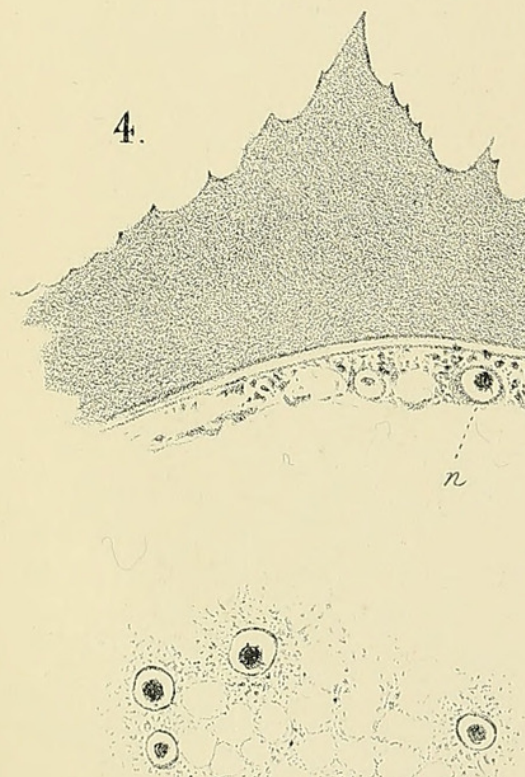

5. ( $(8) \div(0)$ 

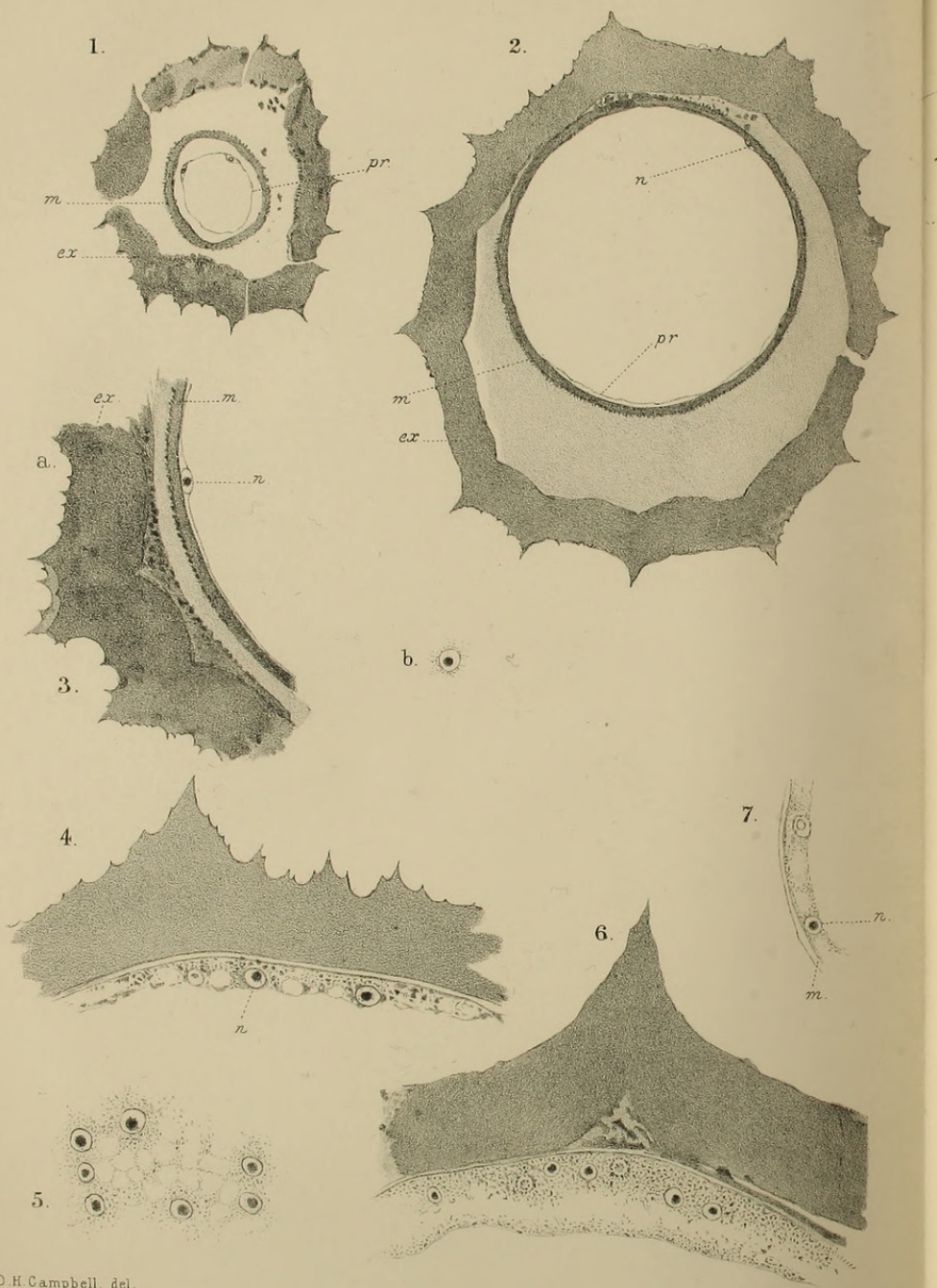

CAMPBELL — GAMETOPHYTE OF SELAGINELLA.
8.

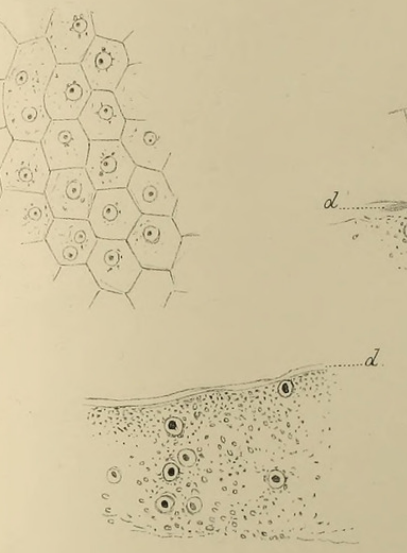

12.

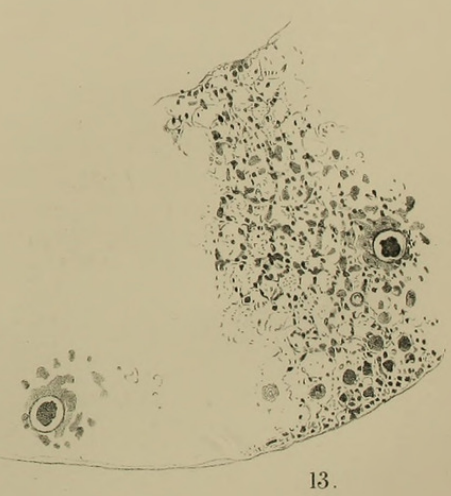

University Press, 0xford.
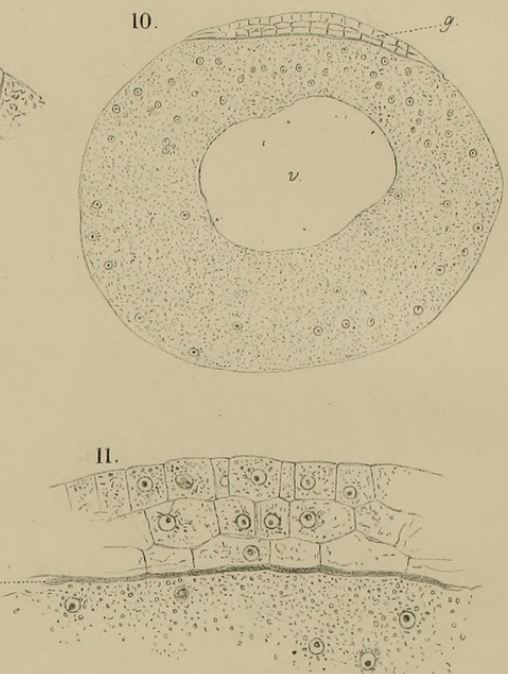

$$
13 .
$$




\section{$2 \mathrm{BHL}$ Biodiversity Heritage Library}

Campbell, Douglas Houghton. 1902. "Studies on the gametophyte of Selaginella." Annals of botany 16, 419-428.

https://doi.org/10.1093/oxfordjournals.aob.a088881.

View This Item Online: https://www.biodiversitylibrary.org/item/233980

DOI: https://doi.org/10.1093/oxfordjournals.aob.a088881

Permalink: https://www.biodiversitylibrary.org/partpdf/318682

\section{Holding Institution}

Smithsonian Libraries

\section{Sponsored by}

Biodiversity Heritage Library

\section{Copyright \& Reuse}

Copyright Status: Not in copyright. The BHL knows of no copyright restrictions on this item.

This document was created from content at the Biodiversity Heritage Library, the world's largest open access digital library for biodiversity literature and archives. Visit BHL at https://www.biodiversitylibrary.org. 